\title{
ORIENTASI KEWIRAUSAHAAN DAN KEMAMPUAN INOVATIF TERHADAP KINERJA UMKM
}

\author{
Felix \\ Program Studi Magister Manajemen Universitas Tarumanagara \\ felixho181@gmail.com
}

Masuk : 07-06-2020, revisi : 26-06-2020 diterima untuk diterbitkan : 29-06-2020

\begin{abstract}
This study aims to analyze the effect of entrepreneurial orientation and innovative abilities on business performance. Entrepreneurial orientation is measured through innovation, proactive, risk-taking, competitive aggressiveness and autonomy, while company performance is measured through financial and non-financial perspectives. The population is SMEs in the Jabodetabek area and obtained with a sample of 259 respondents. The collected data was then analyzed using Smart PLS version 3. The results showed that entrepreneurial orientation positively influenced the performance of companies, especially non-financial. Likewise, innovative capabilities also affect company performance, especially sales.
\end{abstract}

Keywords: Entrepreneurial Orientation, Innovative Capability, Firm Performance, SMEs

Abstrak: Penelitian ini bertujuan untuk menganalisis pengaruh orientasi kewirausahaan dan kemampuan inovaitf terhadap kinerja bisnis. Orientasi kewirausahaan diukur melalui inovasi, proaktif, pengambilan risiko, agresivitas kompetitif dan otonomi, sementara kinerja perusahaan diukur melalui perspektif keuangan dan non keuangan. Populasi adalah UMKM yang berada di wilayah jabodetabek dan diperoleh dengan sampel sebanyak 259 responden. Data yang telah terkumpul kemudian dianalisis menggunakan Smart PLS versi 3. Hasil penelitian menunjukkan bahwa orientasi kewirausahaan mempengaruhi secara positif kinerja perusahaan khususnya non keuangan. Demikian juga dengan kemampuan inovatif juga mempengaruhi kinerja perusahaan khususnya penjualan.

Kata kunci: Orientasi Kewirausahaan, Kemampuan Inovatif, Kinerja Perusahaan, UMKM.

\section{PENDAHULUAN}

Sektor UMKM memiliki peranan yang sangat penting sebagai tulang punggung perekonomian Indonesia. Pada tahun 2018 persentase jumlah UMKM mencapai angka 99,9\% sedangkan jumlah unit usaha besar hanya 0,1\% (Perkembangan Data Usaha Mikro, Kecil, Menengah (UMKM) dan Usaha Besar (UB) Tahun 2015-2018 Kementerian Koperasi dan Kecil dan Menengah, [PDUSKMUB-Kemenkop], 2015-2018). Jumlah tenaga kerja yang dapat diserap oleh UMKM mencapai angka 97\% sedangkan jumlah tenaga kerja yang dapat diserap usaha besar hanya 3\% (PDUSKMUB-Kemenkop, 2015-2018). Pada sisi lain UMKM menyumbangkan sebesar $61,07 \%$ dari total pendapatan domestik bruto di Indonesia, sedangkan jumlah usaha besar hanya mampu menyumbangkan 38,93\% (PDUSKMUB-Kemenkop, 20152018). Oleh karena itu UMKM memiliki peranan yang besar dalam membantu pertumbuhan ekonomi tanah air baik dari sisi penyerapan tenaga kerja maupun dari sisi pendapatan domestik bruto. Salah satu masalah yang sedang dihadapi Indonesia dan dunia adalah pandemic virus COVID-19. Indonesia yang didominasi oleh keberadaan Usaha Mikro, Kecil, dan Menengah (UMKM) terdampak secara serius tidak saja pada aspek total produksi dan nilai perdagangan akan tetapi juga pada jumlah tenaga kerja yang harus kehilangan pekerjaannya karena pandemi ini. Dengan adanya pandemik ini menyebabkan turunnya kinerja dari sisi permintaan (konsumsi dan daya beli masyarakat) yang akhirnya berdampak pada sisi suplai yakni pemutusan hubungan kerja dan ancaman macetnya pembayaran kredit (Pakpahan, 2020). Terdapat 37.000 usaha kecil dan menengah (UKM) yang sangat terpukul oleh pandemi 
COVID-19, sekitar 56\% dari laporan terkait dengan penurunan penjualan, 22\% untuk pendanaan, $15 \%$ untuk distribusi barang dan $4 \%$ untuk mengakses bahan baku (Rahman, R., 16 Mei 2020). Kinerja perusahaan adalah hasil dari serangkaian proses bisnis dengan pengorbanan beragai macam sumber daya yaitu bisa sumber daya manusia dan juga keuangan perusahaan (Moerdiyanto, 2010). Beberapa penelitian terdahulu menunjukan hasil bahwa orientasi kewirausahaan dapat meningkatkan kinerja perusahaan (Herath \& Karunaratne, 2017; Herlinawati et al., 2019; Magaji et al., 2017; Omisakin et al., 2016). Lebih lanjut, Salah satu faktor lainnya yang dapat mempengaruhi kinerja perusahaan adalah kemampuan inovatif. Beberapa penelitian terdahulu menemukan bahawa kemampuan inovatif berpengaruh terhadap kinerja perusahaan (Agyapong et al., 2018; Canh et al., 2019; Yuan et al., 2016)

\section{TELAAH KEPUSTAKAAN}

\section{Resource-Advantage Theory of Competition}

Teori keunggulan kompetitif berbasis sumber daya berfokus pada keunggulan komparatif yang mungkin dimiliki perusahaan dalam sumber daya berwujud dan tidak berwujud (Hunt \& Morgan, 1995). Teori ini menekankan pada pentingnya sumber daya yang tersedia baik berwujud dan tidak berwujud yang memungkinkan perusahaan menghasilkan secara efisien dan efektif penawaran pasar yang memiliki nilai untuk beberapa segmen pasar (Hunt, 1995). Orientasi kewirausahaan, kemampuan inovatif dan kinerja perusahaan dapat dijelaskan melalui teori ini karena orientasi kewirausahaan dan kemampuan inovatif merupakan sumber daya perusahaan tidak berwujud yang dapat dioptimalkan untuk mencapai keunggulan kompetitif dengan kinerja yang superior.

\section{Orientasi Kewirausahaan}

Orientasi kewirausahaan juga dapat diterjemahkan sebagai sebuah mekanisme yang dapat digunakan oleh wirausahawan untuk membantu menghadapi tantangan bisnis seperti keterbatasan akses modal keuangan dan lingkungan usaha yang sangat kompetitif serta peluang bisnis baru yang sangat jarang dijumpai (Wiklund \& Shepherd, 2005). Orientasi kewirausahaan dapat dioperasionalkan melalui dimensi inovasi, pengambilan risiko, dan proaktif (Miller, 1983). Lumpkin dan Dess mengidentifikasi dua dimensi tambahan, otonomi dan agresivitas pesaing, untuk melengkapi tiga dimensi asli yang diusulkan oleh Miller (Lumpkin \& Dess, 1996; Miller, 1983). Dapat disimpulkan orientasi kewirausahaan adalah sikap dasar yang dibutuhkan oleh wirausahawan untuk mencapai tujuan perusahaan dalam menggapai peluang dengan berdasarkan inovasi, pengambilan risiko, proaktif, agresivitas kompetitif, dan otonomi.

\section{Kemampuan Inovatif}

Kemampuan inovatif sebagai kemampuan perusahaan untuk secara cepat menggunakan metode, proses, produk, dan layanan baru dalam menanggapi lingkungan bisnis yang berubah, sehingga memperoleh keunggulan kompetitif (Agyapong et al., 2018). Kemampuan inovatif mengacu pada kemampuan perusahaan untuk menggunakan sumber daya dan keterampilan kolektif semua aktor untuk kegiatan inovatif yang melibatkan produk, layanan, proses, dan sistem organisasi baru, untuk untuk menambah nilai bagi organisasi (Weerawardena \& McColl-Kennedy, 2002). Dapat disimpulkan kemampuan inovatif adalah kemampuan perusahaan untuk mengadaptasi metode, proses, teknologi, produk dan layanan baru dalam menghadapi perubahan lingkungan dan mencapai tujuan perusahaan.

\section{Kinerja Perusahaan}

Dalam konteks manajemen perusahaan, kinerja organisasi seperti seberapa baik organisasi dikelola dan nilai organisasi memberikan untuk pelanggan dan pemangku kepentingan lainnya. Untuk mencapai kinerja relatif yang unggul, organisasi harus mencapai yang diharapkan secara obyektif dengan efisiensi dan efektivitas yang lebih besar untuk menyamai para pesaingnya (Wu \& Zhao, 2009). Kinerja perusahaan adalah hasil dari serangkaian proses bisnis yang mana dengan pengorbanan beragai macam sumber daya yaitu bisa sumber daya manusia dan juga keuangan perusahaan (Moerdiyanto, 2010). Dapat 
disimpulkan bahwa kinerja perusahaan merupakan hasil dari sebuah proses bisnis yang dilakukan secara terus menerus untuk mencapai tujuan perusahaan.

\section{Kaitan antar Variabel}

\section{Orientasi Kewirausahaan dapat memprediksi secara positif kinerja perusahaan}

Orientasi kewirausahaan sebagai orientasi untuk menjadi yang pertama dalam hal inovasi di pasar, memiliki sikap untuk mengambil risiko, dan proaktif terhadap perubahan yang terjadi pasar (Miller, 1983). Dengan menggunakan pendekatan Resource-Advantage Theory of Competition yang berfokus pada bagaimana perusahaan mengelola segala keunggulan sumber daya secara efektif dan efisien agar dapat mencapai kinerja superior melalui posisi keunggulan kompetitif di beberapa segmen pasar. Perusahaan yang dikelola dengan orientasi kewirausahaan memiliki sikap dasar dalam mengelola segala sumber daya perusahaan dalam mencapai keunggulan kompetitif sehingga mampu untuk mencapai kinerja yang diharapkan.

\section{Kemampuan Inovatif dapat memprediksi secara positif kinerja perusahaan}

Untuk mendapatkan keunggulan kompetitif dan bertahan dari persaingan, pelaku industri harus mengembangkan strategi inovatif untuk pengembangan produk / layanan baru, proses, dan cara baru membangun hubungan pelanggan, sehingga menarik lebih banyak pelanggan (Agyapong et al., 2018). Inovasi membuat produk / layanan lebih menarik dalam hal fitur atau harga, membantu perusahaan dalam mempertahankan pangsa pasar atau bahkan mendapatkan lebih banyak pelanggan (Canh et al., 2019). Dengan menggunakan pendekatan ResourceAdvantage Theory of Competition bahwa perusahaan dituntut untuk selalu berinovasi maka perusahaan dengan kemampuan inovatif akan mampu memanfaatkan segala sumber daya yang ada untuk dapat menciptakan produk/layanan baru sehingga dapat menjangkau lebih banyak pelanggan dan dapat mengungguli persaingan bisnis sehingga menghasilkan kinerja perusahaan yang lebih baik.

Berdasarkan uraian kaitan antar variabel sebelumnya, maka model penelitian adalah sebagai berikut:

$\underset{\text { Kemampuan Inovatif (X2) }}{\stackrel{\text { Orientasi Kewirausahaan (X1) }}{\longrightarrow} \longrightarrow \text { Kinerja Perusahaan (Y) }}$

\section{Gambar 1 \\ Model Penelitian}

Berdasarkan paparan di atas, maka hipotesis penelitian adalah sebagai berikut:

H1 : Orientasi kewirausahaan berpengaruh positif terhadap kinerja perusahaan

$\mathrm{H} 2$ : Kemampuan inovatif berpengaruh positif terhadap kinerja perusahaan

\section{METODOLOGI PENELITIAN}

Desain penelitian ini adalah penelitian deskriptif dengan metode cross sectional design. Populasi dalam penelitian ini adalah seluruh pelaku UMKM. Metode pengambilan sampel dalam penelitian ini adalah metode non-probability sampling yang artinya responden dipilih berdasarkan kriteria yang ditentukan yaitu pelaku UMKM diwilayah Jabodetabek. Jumlah Sampel dalam penelitian ini sebanyak 259 responden. Data dikumpulkan dengan menggunakan google formulir yang disebarkan melalui media sosial. Berdasarkan data yang telah dikumpulkan, diketahui bahwa mayoritas responden memiliki jenis bidang usaha perdagangan, yaitu sebesar 47\%. Mayoritas usaha didirikan pada tahun 2017 sebanyak 10\%.

Objek penelitian diukur menggunakan skala Likert sepuluh poin dikarenakan kebiasaan menilai seuatu dari angka terendah satu dan tertinggi sepuluh. Tabel 1 menunjukan pengukuran masing-masing variabel dan sumbernya, instrumen tersebut telah dilakukan analisis validitas dengan hasil analisis convergent validity yaitu nilai loading factor seluruh indikator seluruh variabel menunjukan hasil diatas 0,6 dan nilai AVE seluruh variabel lebih besar dari 0,5. Kemudian untuk analisis discriminant validity menunjukan nilai cross loading tiap indikator variabelnya lebih besar dari korelasi antar variabel lainnya dan analisis fornell-larcker 
menunjukan nilai akar kuadrat AVE lebih besar dari korelasi antar variabel lainnya sehingga seluruh instrumen dinyatakan valid. Sementara untuk analisis reliabilitas didasarkan pada nilai cronbach's alpha dan composite reliability yang masing-masing hasilnya menunjukan nilai lebih dari 0,7 sehingga semua indikator dalam penelitian adalah reliabel (Hair et al., 2011)

Metode analisis data dalam penelitian ini menggunakan structure equation modeling (SEM) dengan bantuan program SmartPLS 3.3.2. taraf signifikansi yang digunakan pada penelitian ini adalah sebesar $5 \%$.

Tabel 1

Variabel data Pengukuran

\begin{tabular}{|l|c|c|}
\hline Variabel & Jumlah Item & Sumber \\
\hline Variabel Bebas & & (Dess \& Lumpkin, 2005) \\
$\begin{array}{l}\text { 1. Orientasi Kewirausahaan } \\
\text { 2. Kemampuan Inovatif }\end{array}$ & 28 & (Lee \& Lim, 2009) \\
\hline $\begin{array}{l}\text { Variabel Terikat } \\
\text { 1. Kinerja Perusahaan }\end{array}$ & 7 & (Jalali et al., 2013) \\
\hline
\end{tabular}

\section{Hasil Uji Statistik}

Hasil pengujian koefisien determinasi $\mathrm{R}^{2}$ dari penelitian ini menunjukan nilai presentase variabel purchase decision sebesar $47,8 \%$ yang berarti variabel kinerja perusahaan dapat dijelaskan oleh variabel orientasi kewirausahaan dan kemampuan inovatif dan sisanya sebesar $52,2 \%$ dari variabel kinerja perusahaan dapat dijelaskan oleh variabel lain diluar penelitian ini (Hair et al., 2011). Berdasarkan hasil tersebut, maka koefisien determinasi pada penelitian ini tergolong moderat.

Hasil analisis data secara singkat tertera pada Tabel 2. berikut ini:

\section{Tabel 2}

Hasil Pengujian Hipotesis

\begin{tabular}{lll}
\hline Hipotesis & Coefficient & T-statistic \\
\hline Orientasi Kewirausahaan -> Kinerja Perusahaan Non Keuangan & 0.836 & $8.588^{* * *}$ \\
\hline Orientasi Kewirausahaan -> Kinerja Perusahaan Penjualan & 0.055 & 0.621 \\
\hline Orientasi Kewirausahaan -> Kinerja Perusahaan Profit & 0.126 & 1.054 \\
\hline Kemampuan Inovatif -> Kinerja Perusahaan Non Keuangan & -0.182 & $1.701 *$ \\
\hline Kemampuan Inovatif -> Kinerja Perusahaan Penjualan & 0.192 & $1.997 * *$ \\
\hline Kemampuan Inovatif -> Kinerja Perusahaan Profit & 0.176 & 1.394 \\
\hline$* * *<0,01 \cdot * * p<0,05 ; * p<0,1$ & &
\end{tabular}

$* * * \mathrm{p}<0,01 ; * * \mathrm{p}<0,05 ; * \mathrm{p}<0,1$

Berdasarkan Tabel 2. dapat ditarik kesimpulan bahwa variabel orientasi kewirausahaan memberikan kontribusi terbesar terhadap prediksi kinerja perushaaan khususnya non keuangan yang dibuktikan oleh nilai path coefficients yaitu sebesar 0.836 dan diketahui variabel kemampuan inovatif memberikan kontribusi terhadap prediksi kinerja perusahaan khususnya penjualan sebesar 0,192. Sementara untuk hasil pengujian seluruh hipotesis, variabel orientasi kewirausahaan dan kemampuan inovatif terbukti mampu memprediksi secara positif kinerja perusahaan.

\section{Diskusi}

Variabel orientasi kewirausahaan mempengaruhi kinerja perusahaan khususnya non keuangan. Hasil tersebut menunjukan bahwa orientasi kewirausahaan membuat pelaku UMKM untuk bertindak lebih proaktif dalam mengelola perusahaan sehingga dapat mencapai kinerja atau target yang telah ditetapkan. Meskipun kinerja atau target telah dicapai, namum hal tersebut tidak berpengaruh terhadap kinerja keuangan baik secara penjualan maupun profit, hal ini diduga karena target yang ditetapakan bersifat subjektif oleh masing-masing pelaku UMKM sehingga mereka merasa telah mencapai target yang telah ditetapkan namun belum menghasilkan kinerja keuangan yang melampaui batas. Hasil penelitian ini sesuai dengan penelitian terdahulu yang dilakukan oleh (Herath \& Karunaratne, 2017; Herlinawati et al., 2019; Magaji et al., 2017; Omisakin et al., 2016) bahwa orientasi kewirausahaan secara positif memprediksi kinerja perusahaan UMKM. 
Kemampuan inovatif mampu meningkatkan kinerja secara penjualan namun orientasi kewirausahaan belum mampu mempengaruhi kinerja profit yang mungkin disebabkan biaya memasarkan produk atau pun jasa yang lebih besar sehingga kurangnya efisiensi yang mengakibatkan profit menjadi berkurang. Hasil penelitian ini sesuai dengan penelitian terdahulu yang dilakukan oleh (Agyapong et al., 2018; Canh et al., 2019; Yuan et al., 2016) bahwa orientasi kewirausahaan secara positif memprediksi kinerja perusahaan UMKM.

\section{KESIMPULAN DAN SARAN}

Hasil penelitian memberikan saran agar orientasi kewirausahaan perlu terus didorong untuk meningkatkan kinerja perusahaan, salah satu indikator proaktif yaitu memperkenalkan produk dan teknologi baru perlu terus dikembangkan karena indikator tersebut merupakan yang paling dominan dalam mempengaruhi kinerja perusahaan khususnya non keuangan. Kemampuan inovatif perlu terus didorong untuk meningkatkan kinerja perusahaan, indikator produk/jasa baru perlu terus ditingkatkan karena merupakan indikator yang paling dominan.

Bagi peneliti selanjutnya disarankan agar jumlah sampel dan cakupan wilayah dapat diperluas lagi, sehingga dapat memperkuat dan melengkapi penelitian sebelumnya. Selanjutnya dapat menganalisis faktor lainnya yang diduga memiliki pengaruh pada faktor yang mempengaruhi kinerja perusahaan, dapat pula mengembangkan penelitian ini dengan menggunakan analisis data lain dengan membandingkan dengan beberapa wilayah lainnya.

\section{DAFTAR RUJUKAN/PUSTAKA}

Agyapong, A., Mensah, H. K., \& Ayunni, A. M. (2018). The moderating role of social network on the relationship between innovative capability and performance in the hotel industry. International Journal of Emerging Markets. https://doi.org/10.1108/JFM-03-2013-0017

Aladejebi, \& A, O. (2018). Predictors of firm performance among selected SMEs in Lagos, Nigeria Predictors of firm performance among selected SMEs in Lagos, Nigeria. 4(June), $8-17$.

Canh, N. T., Liem, N. T., Thu, P. A., \& Khuong, N. V. (2019). The impact of innovation on the firm performance and corporate social responsibility of Vietnamese manufacturing firms. Sustainability (Switzerland), 11(13). https://doi.org/10.3390/su11133666

Dess, G. G., \& Lumpkin, G. T. (2005). The role of entrepreneurial orientation in stimulating effective corporate entrepreneurship. Academy of Management Executive, 19(1), 45-46. https://doi.org/10.1177/002248718203300610

Hair, J. F., Ringle, C. M., \& Sarstedt, M. (2011). PLS-SEM: Indeed a silver bullet. Journal of Marketing Theory and Practice, 19(2), 139-152. https://doi.org/10.2753/MTP10696679190202

Herath, H. M. T. S., \& Karunaratne, H. D. (2017). Entrepreneurial orientation of information and communication technology services exports in Sri Lanka. Journal of Business and Economics, 8(7), 573-583. https://doi.org/10.15341/jbe(2155-7950)/07.08.2017/006

Herlinawati, E., Suryana, Ahman, E., \& Machmud, A. (2019). Pengaruh orientasi wirausaha terhadap kinerja bisnis UKM di Indonesia. Jurnal Pendidikan Kewirausahaan, 22(5), 19.

Hunt, S. D. (1995). The resource-advantage theory of competition: toward explaining productivity and economic growth. Journal of Management Inquiry, 4(4), 317-332. https://doi.org/10.1177/105649269500400403

Hunt, S. D., \& Morgan, R. M. (1995). The comparative advantage theory of competition. Journal of Marketing, 59(2), 1. https://doi.org/10.2307/1252069

Jalali, A., Jaafar, M., \& Thurasamy, R. (2013). Influence of entrepreneurial orientation on the financial performance: evidence from SMEs in Iran. Middle East J. of Management, 1(2), 168. https://doi.org/10.1504/mejm.2013.057263

Kementerian Koperasi dan Kecil dan Menengah. (2020). Perkembangan Data Usaha Mikro, 
Kecil, Menengah (UMKM) Dan Usaha Besar (UB) Tahun 2015 - 2018. Retrieved 01 May, 2020, from KEMENKOP website http://www.depkop.go.id/data-umkm

Lee, S. M., \& Lim, S. (2009). Entrepreneurial orientation and the performance of service business. Service Business, 3(1), 1-13. https://doi.org/10.1007/s11628-008-0051-5

Lumpkin, G. T., \& Dess, G. G. (1996). Clarifying the entrepreneurial orientation construct and linking it to performance. Academy of Management Review, 21(1), 135-172. https://doi.org/10.2307/258632

Magaji, M. S., Baba, R., \& Entebang, H. (2017). Entrepreneurial orientation and financial performance of Nigerian SMES: The moderating role of environment. A Review of literature. Journal of Management and Training for Industries, 4(1), 25-41. https://doi.org/10.12792/jmti.4.1.25

Miller, D. (1983). The correlates of entrepreneurship in three types of firms. Management Science, 29(7), 770-791. https://doi.org/10.1287/mnsc.29.7.770

Moerdiyanto. (2010). Tingkat pendidikan manajer dan kinerja perusahaan go-public. FISE Universitas Negeri Yogyakarta, 1-18.

Omisakin, O. M., Nakhid, C., Littrell, R., \& Verbitsky, J. (2016). Entrepreneurial orientation among migrants and small and medium enterprises. Journal of Business Administration Research, 5(1), 7-22. https://doi.org/10.5430/jbar.v5n1p7

Pakpahan, A. K. (2020). Covid-19 dan implikasi bagi usaha mikro, kecil, dan menengah. JIHI: Jurnal Ilmu Hubungan Internasional, 20(April), 2-6. https://doi.org/https://doi.org/10.26593/jihi.v0i0.3870.59-64

Rahman, Riska. (2020). 37,000 SMEs hit by COVID-19 crisis as government prepares aid. Retrieved 06 June, 2020, from https://www.thejakartapost.com/news/2020/04/16/37000smes-hit-by-covid-19-crisis-as-government-prepares-aid.html

Weerawardena, J., \& McColl-Kennedy, J. R. (2002). New service development and competitive advantage: A conceptual model. Australasian Marketing Journal (AMJ), 10(1), 13-23. https://doi.org/10.1016/s1441-3582(02)70140-7

Wiklund, J., \& Shepherd, D. (2005). Entrepreneurial orientation and small business performance: A configurational approach. Journal of Business Venturing, 20(1), 71-91. https://doi.org/10.1016/j.jbusvent.2004.01.001

Wu, D., \& Zhao, F. (2009). Measuring performance in small and medium enterprises in the information \& communication technology industries (Issue February).

Yuan, X., Shin, S., He, X., \& Yong Kim, S. (2016). Innovation capability, marketing capability and firm performance: A two-nation study of China and Korea. Asian Business and Management, 15(1), 32-56. https://doi.org/10.1057/abm.2015.17 